\title{
PELATIHAN PLYOMETRIC DENGAN DEPTH JUMP MENINGKATKAN DAYA LEDAK OTOT TUNGKAI LEBIH BESAR DARIPADA PELATIHAN STANDING JUMP PADA PEMAIN BOLA VOLI PUTRA
}

\author{
I Gede Widyatmika Pratama ${ }^{1}$, Ketut Tirtayasa ${ }^{2}$, Gde Ngurah Indraguna Pinatih ${ }^{3}$, Putu \\ Gede Adiatmika ${ }^{4}$, Made Muliarta ${ }^{5}$, Putu Adiartha Griadhi ${ }^{6}$ \\ ${ }^{1}$ Program Studi Fisiologi keolahragaan Universitas Udayana \\ 2,3,4,5,6 Fakultas Kedokteran Universitas Udayana Denpasar Bali
}

\begin{abstract}
ABSTRAK
Pendahuluan: Permainan bola voli merupakan olahraga populer yang bersifat kompetitif. Dalam permainan bola voli para pemain dituntut untuk memainkan bola diatas net. Faktor fisik yang menunjang kemampuan tersebut adalah daya ledak otot tungkai. Salah satu upaya dalam usaha peningkatan daya ledak otot tungkai melalui latihan plyometric. Pelatihan yang diberikan pada penelitian ini adalah pelatihan plyometric depth jump dan standing jump terhadap peningkatan daya ledak otot tungkai. Tujuan: untuk membandingkan efek kedua jenis pelatihan tersebut terhadap peningkatan daya ledak otot tungkai. Metode: Penelitian ini menggunakan metode eksperimental rancangan Pre Test and Post Test Group Design selama enam minggu dengan frekuensi pelatihan tiga kali dalam seminggu. Jumlah sampel 22 orang yang dibagi menjadi dua kelompok berdasarkan ordinal pairing. Kelompok I diberikan pelatihan plyometric depth jump dan kelompok II diberikan pelatihan standing jump. Hasil pengukuran daya ledak otot tungkai didapat dari tes vertical jump menggunakan alat jump $M D$, yang diukur sebelum dan sesudah pelatihan pada masing-masing kelompok. Selanjutnya hasil rerata dibandingkan dengan uji statistik $t$ - paired test. Hasil: Rerata daya ledak otot tungkai Kelompok I sebelum pelatihan 39,73 $\pm 3,74 \mathrm{~cm}$ dan setelah pelatihan 55,64 \pm 4,03 cm secara statistik menunjukkan nilai $\mathrm{p}$ berbeda bermakna $(\mathrm{p}<0,05)$. Sedangkan pada pelatihan kelompok II sebelum pelatihan $39,73 \pm 3,58 \mathrm{~cm}$ dan setelah pelatihan $51,36 \pm 3,85 \mathrm{~cm}$ secara statistik berbeda bermakna $(\mathrm{p}<0,05)$. Peningkatan daya ledak otot tungkai antara ke dua kelompok menunjukkan perbedaan hasil yang bermakna $(\mathrm{p}<0,05)$. Persentase peningkatan kelompok plyometric depth jump sebesar 40, $05 \%$ sedangkan pada kelompok standing jump 29,27\%. Simpulan: pelatihan plyometric depth jump meningkatkan daya ledak otot tungkai lebih besar daripada pelatihan standing jump pada siswa peserta ekstrakurikular bola voli putra SMK Triatma Jaya Badung.
\end{abstract}

Kata kunci : Pelatihan Plyometric Depth Jump dan Standing Jump, Daya Ledak Otot Tungkai, Olahraga Permainan Bola Voli.

\section{PLYOMETRIC EXERCISE WITH DEPTH JUMP INCREASING EXPLOSION POWER OF LEGS MUSCLES IS BIGGER THAN STANDING JUMP EXERCISES ON THE MEN'S VOLLEYBALL PLAYER}

\begin{abstract}
Background: Volleyball is a popular sport that is competitive. In volleyball, the volleyball player must play the volleyball over the net. The physical factor that supports that ability is explosion power of legs muscles. One of the ways to increase the explosion power of legs muscles is plyometric exercise. The exercises that were given in this research were plyometric depth jump and standing jump exercises to increase the explosion power of legs
\end{abstract}


muscles. Purpose: The objective of this exercise is to compare the effect of both exercises for increasing the explosion power of legs muscles. Method: This research used experimental method Pre Test and Post Test Group Design in six weeks and frequency of three times a week. The samples are 22 people who are divided into two groups through ordinal pairing technique. The first group was given plyometric depth jump exercise and the second group was given standing jump exercise. The measurement of the explosion power of legs muscles used jump MD that was measured before and after exercises in every groups. Next, the average result was compared with statistical test of t- paired test. Result: The average of the explosion power of legs muscles pre test of the first group was $39.73 \pm 3.74$ centimeters and the post test was 55.64 \pm 4.03 centimeters are statistically significant $(\mathrm{p}<0.05)$. Otherwise, on the second group, the pre test was $39.73 \pm 3.58$ centimeters and the post test was $51.36 \pm 3.85$ centimeters are statistically significant $(\mathrm{p}<0.05)$. The increasing of the explosion power of legs muscles between both groups are significant $(\mathrm{p}<0.05)$. The percentage of increasing of plyometric depth jump was $40.05 \%$ and for the standing jump was $29.27 \%$. Conclusion: Plyometric depth jump increased the explosion power of legs muscles is bigger than standing jump exercise for all students on the men's volleyball extracurricular of SMK Triatma Jaya Badung.

Keywords : Plyometric depth jump and standing jump exercises, the explosion power of legs muscles, volleyball.

\section{PENDAHULUAN}

Salah satu tujuan berolahraga adalah untuk meningkatkan prestasi. Sasaran pencapaian penampilan maksimal meliputi beberapa faktor, diantaranya (a) meningkatkan kemampuan fisik secara umum, (b) menyempurnakan teknik, (c) mengembangkan taktik dan strategi, (d) dan meningkatkan kualitas kemampuan psikis ${ }^{1}$.

Pelatihan adalah upaya untuk meningkatkan kemampuan dasar yang dimiliki seseorang guna mencapai tujuan yang diinginkan. Pelatihan menyebabkan seseorang memiliki daya adaptasi maksimal, baik fisik, psikologis, teknis dan praktis guna melahirkan kinerja yang optimal dalam menghadapi tantangan dan kompetisi dengan penuh konsentrasi ${ }^{2}$.

Pelatihan fisik merupakan suatu proses pembebanan dalam tubuh secara sistematis untuk mewujudkan rangsangan yang menyebabkan timbulnya adaptasi fisiologis kerja tubuh ${ }^{2}$. Peningkatan kemampuan fisik yang baik sangat berpengaruh pada sistem sirkulasi kerja jantung, ekonomi gerak yang baik pada waktu lain dan pemulihan organisme tubuh yang lebih cepat apabila sewaktu-waktu respon diperlukan ${ }^{3}$.
Berdasarkan pengamatan di SMK Triatma Jaya Badung dari tahun 2011 sampai 2016 belum memperoleh hasil yang maksimal dalam permainan bola voli pada Pekan Olahraga Pelajar Kabupaten Badung. Kelemahan yang terlihat pada team bola voli putra di SMK Triatma Jaya Badung terletak pada kemampuan fisik daripada pemain yang kemungkinan disebabkan oleh teknik bermain, kondisi fisik, atau bentuk pelatihan yang diterapkan.Teknik dasar yang diterapkan dalam permainan bola voli meliputi atas: service, passing, smash, dan blocking ${ }^{4}$.

Kemampuan sebuah team bola voli ditentukan dari keterampilan teknik dasar yang dikuasai oleh setiap anggota team dalam melakukan fungsinya masingmasing ${ }^{4}$. Pada dasarnya permainan yang dibatasi oleh ketinggian net menuntut pemain mempunyai daya ledak otot tungkai yang baik guna memaksimalkan kemampuan teknik dasar smash dan block dalam mencetak point untuk memperoleh kemenangan.

Dalam permainan bola voli yang menjadi sasaran terhadap membaiknya komponen kondisi fisik pada daya ledak otot tungkai. Daya ledak merupakan kemampuan dari bagian tubuh yang 
berkontraksi secara cepat untuk dapat melakukan aktivitas secara tiba-tiba ${ }^{2}$. Daya ledak otot tungkai ditandai dengan adanya gerakan otot yang tiba-tiba secara cepat dan maksimal, berupa gerakan tubuh terdorong ke atas atau terdorong kearah depan $^{2}$.

Pelatihan daya ledak otot tungkai sangat berkaitan dengan tipe gerak plyometric. Pelatihan plyometric merupakan tipe pelatihan yang ditujukan untuk mengembangkan daya ledak eksplosive dengan gabungan kekuatan dan kecepatan kontraksi otot ${ }^{5}$. Pelatihan plyometric menekankan pada prinsip latihan selalu berkontraksi baik saat memanjang maupun memendek. Takaran pelatihan untuk daya ledak dalam repetisi sedang memiliki intensitas $70 \%$ sampai $85 \%$ dari kemampuan maksimal, repetisi 5 sampai 10 kali ulangan, jumlah set 3 sampai 5 dan waktu istirahat 2 sampai 4 menit ${ }^{2}$.

Pelatihan yang tepat dapat meningkatkan kemampuan komponen biomotorik yang dominan diperlukan dalam permainan bola voli. Peserta ekstra kurikuler bola voli putra di SMK Triatma Jaya Badung hanya berpedoman pada pelatihan standing jump. Dalam usaha peningkatan daya ledak otot tungkai, menerapkan pola latihan baru dengan memodifikasi pelatihan standing jump dengan pelatihan plyometric depth jump pada peserta ekstra kurikuler bola voli putra di SMK Triatma Jaya Badung.

\section{METODE PENELITIAN}

\section{Rancangan Penelitian}

Penelitian ini menggunakan rancangan Experimental Pretest and Posttest Group Design yang membandingkan dua bentuk kelompok perlakuan. Kelompok I diberikan pelatihan plyometric depth jump dan kelompok II diberikan pelatihan standing jump.

\section{Lokasi dan Waktu Penelitian}

Penelitian dilakukan di SMK Triatma Jaya Badung dengan waktu penelitian selama enam minggu. Frekuensi latihan tiga kali seminggu, yaitu pada sore hari mulai pukul 15.00 WITA hingga selesai.

\section{Populasi dan Sampel}

Populasi pada penelitian meliputi seluruh peserta ekstrakurikuler bola voli putra SMK Triatma Jaya Badung. Sampel yang digunakan pada penelitian ini adalah populasi yang memenuhi kriteria inklusi dan eksklusi.

\section{Prosedur Penelitian}

Langkah yang dilaksanakan pada prosedur penelitian ini yaitu: 1.Mempersiapkan surat izin penelitian yang ditujukan kepada kepala sekolah SMK Triatma Jaya Badung untuk menggunakan peserta ekstra kurikuler bola voli putra sebagai sampel penelitian. 2.Pengambilan biodata subjek, dilanjutkan dengan pengukuran berat badan subjek, tinggi badan, panjang tungkai dan kebugaran fisik subjek tersebut. 3.Menetapkan jumlah sampel sesuai dengan rumus Pocock ${ }^{6}$ dengan penelitian awal terhadap lima orang calon sampel. 4.Melaksanakan tes kemampuan daya ledak otot tungkai melalui tes vertical jump sebelum pelaksanaan pelatihan. Test vertical jump dilaksanakan dengan cara subjek melakukan tolakan menggunakan alat jump MD. Pengukuran dilakukan sebanyak tiga kali dan tercatat hasil yang paling maksimal. 5.Pembentukan kelompok penelitian dengan Ordinal Pairing. 6.Melaksanakan pelatihan pada masing-masing kelompok pelatihan dengan frekuensi latihan tiga kali perminggu selama enam minggu ${ }^{2}$. Kelompok I diberikan pelatihan plyometric depth jump yang merupakan bentuk yang bertujuan untuk melatih kemampuan daya ledak otot tungkai. Pelatihan ini adalah tipe pelatihan yang dinamis turun dari atas box ke tanah dan melakukan loncatan eksplosif ke atas box berikutnya.

Kelompok II diberikan pelatihan standing jump yang di laksanakan dengan cara melakukan loncatan ke depan atas meloncati rintangan dengan kaki ditekuk dan melakukan pendaratan dengan dua 
kaki. 7.Melaksanakan tes kemampuan daya ledak otot tungkai menggunakan tes vertical jump setelah pelatihan selesai selama enam minggu. 8.Menganalisis data hasil tes sebelum dan sesudah pelaksanaan latihan.

Langkah-langkah yang dilakukan dalam pengukuran variabel pada penelitian, yaitu: 1.Pengukuran berat badan dengan cara subjek berdiri tegak di atas timbangan dengan berpakaian minimal tanpa alas kaki, kemudian hasil pengukuran dicatat dalam satuan kilogram. 2.Pengukuran tinggi badan dengan mengukur subjek yang berdiri tegak tanpa alas kaki dari lantai sampai vertek dalam satuan centimeter. 3.Pengukuran panjang tungkai dilakukan dari mata kaki sampai pangkal paha dalam satuan centimeter. 4.Pengukuran kebugaran fisik dengan cara mencatat waktu subjek berlari menempuh jarak 2,4 kilometer. 5.Melakukan pengukuran hasil daya ledak otot tungkai melalui tes vertical jump menggunakan alat Jump MD.

\section{Operasional Variabel}

Operasional variabel pada pelatihan ini antara lain: 1.Pelatihan plyometric depth jump adalah salah satu bentuk pelatihan dinamis yang pelaksanaanya subjek berdiri di atas box dengan ketinggian 50 centimeter kemudian meloncat ke bawah dari box dilanjutkan meloncat kembali ke box berikutnya. 2.Pelatihan standing jump adalah bentuk latihan meloncat ke depan atas dengan dua kaki melewati penghalang dengan ketinggian $50 \mathrm{~cm}$ dan mendarat dengan dua kaki. 3.Ordinal pairing adalah bentuk pemisahan sampel menjadi dua kelompok pelatihan yang di dasari atas kriterium atau perengkingan dari hasil test awal. 4.Test vertical jump adalah alat untuk mengukur kemampuan daya ledak otot tungkai. Prosedur pelaksanaan tes, subjek berdiri di atas ruberr plate, tekan tombol start kemudian meloncat dengan tegak setinggitingginya. Pengukuran hasil daya ledak otot tungkai dilaksanakan sebanyak tiga kali dan hasil yang digunakan adalah tolakan tertinggi dalam satuan centimeter.

\section{HASIL PENELITIAN}

\section{Karakter Subjek Penelitian}

Karakter subjek penelitian ini meliputi: berat badan, tinggi badan, panjang tungkai, dan kebugaran fisik. Hasil deskripsi karakteristik subjek penelitian

Tabel 1

Karakter Subjek Penelitian

\begin{tabular}{|c|c|c|c|}
\hline \multirow[t]{2}{*}{$\begin{array}{l}\text { Karakter } \\
\text { subjek } \\
\text { penelitian }\end{array}$} & & $\begin{array}{l}\text { Kelompok } \\
\text { plyometric } \\
\text { depth jump }\end{array}$ & $\begin{array}{l}\text { Kelompok } \\
\text { standing } \\
\text { jump }\end{array}$ \\
\hline & $\mathrm{N}$ & Rerata \pm SB & Rerata $\pm \mathrm{SB}$ \\
\hline $\begin{array}{l}\text { Tinggi } \\
\text { Badan }(\mathrm{cm})\end{array}$ & 11 & $\begin{array}{l}166,09 \pm \\
1,30\end{array}$ & $\begin{array}{l}166,09 \pm \\
1,30\end{array}$ \\
\hline $\begin{array}{l}\text { Berat Badan } \\
(\mathrm{kg})\end{array}$ & 11 & $58,00 \pm 2,60$ & $59,09 \pm 2,59$ \\
\hline $\begin{array}{l}\text { Panjang } \\
\text { Tungkai } \\
(\mathrm{cm})\end{array}$ & 11 & $88,20 \pm 1,73$ & $87,98 \pm 1,96$ \\
\hline $\begin{array}{l}\text { Kebugaran } \\
\text { Fisik (menit) }\end{array}$ & 11 & $11,68 \pm 1,37$ & $11,51 \pm 1,50$ \\
\hline
\end{tabular}

\section{Karakteristi Lingkungan Penelitian}

Hasil pengukuran suhu di lapangan selama pelatihan disesuaikan dengan tabel psycometric chart dalam \% dan kelembaban suhu dalam satuan ${ }^{0} \mathrm{C}$. Hasil Deskripsi Karakteristik Lingkungan Penelitian

Tabel 2

Suhu Lingkungan Penelitian

\begin{tabular}{lllll}
\hline $\begin{array}{l}\text { Suhu } \\
\text { Lingkungan }\end{array}$ & $\mathrm{n}$ & Rerata $\pm \mathrm{SB}$ & $\begin{array}{l}\text { Minim } \\
\text { al }\end{array}$ & $\begin{array}{l}\text { Maksi } \\
\text { mal }\end{array}$ \\
\hline $\begin{array}{l}\text { Suhu Kering } \\
\left({ }^{0} \mathrm{C}\right)\end{array}$ & 18 & $28,54 \pm 0,77$ & 27,1 & 30 \\
Suhu Basah $\left({ }^{\circ} \mathrm{C}\right)$ & 18 & $25,38 \pm 0,47$ & 24,7 & 26 \\
Kelembaban $(\%)$ & 18 & $70,06 \pm 11,28$ & 65,0 & 78 \\
\hline
\end{tabular}

\section{Hasil Rerata Beda Daya Ledak Otot Tungkai Antar Kelompok}

Analisis uji beda rerata digunakan untuk membandingkan beda hasil rerata daya ledak otot tungkai sebelum dan sesudah pelatihan. Antara kelompok I pelatihan plyometric depth jump dengan kelompok II pelatihan standing jump. Hasil analisis kemaknaan menggunakan uji $t$-independent (tidak berpasangan). 
Tabel 5.4

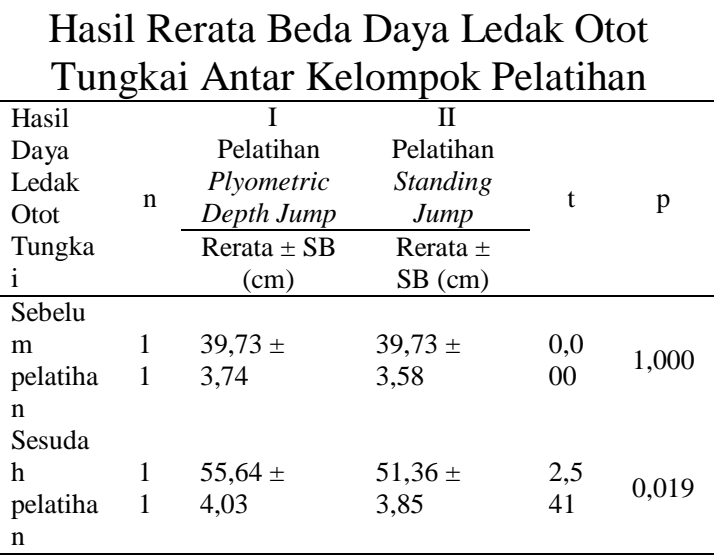

Hasil rerata daya ledak otot tungkai sebelum pelatihan pada kedua kelompok memiliki nilai $\mathrm{p}$ yang lebih besar dari 0,05 . Sehingga disimpulkan bahwa rerata daya ledak otot tungkai sebelum pelatihan antara kelompok plyometric depth jump dengan kelompok standing jump adalah sebanding. Kemudian setelah melaksanakan pelatihan antara kelompok plyometric depth jump dengan kelompok standing jump memiliki nilai $\mathrm{p}$ yang lebih kecil dari 0,05 . Hasil daya ledak otot tungkai setelah pelatihan antara kelompok plyometric depth jump dan kelompok standing jump memiliki perbedaan yang bermakna.

\section{Hasil Rerata Beda Daya Ledak Otot Tungkai Sebelum dan Sesudah Pelatihan pada kedua Kelompok}

Uji t-paired test (uji t berpasangan) digunakan untuk menunjukkan perbedaan hasil rerata daya ledak otot tungkai antara sebelum dan sesudah pelatihan pada kelompok plyometric depth jump dan kelompok pelatihan standing jump, dengan $\alpha=0,05$.
Tabel 5.5

Hasil Beda Rerata Daya Ledak Otot Tungkai Sebelum dan Sesudah Pelatihan

\begin{tabular}{|c|c|c|c|c|}
\hline \multirow[b]{2}{*}{$\begin{array}{l}\text { Pelatih } \\
\text { an }\end{array}$} & \multicolumn{2}{|c|}{$\begin{array}{c}\text { Rerata Hasil Daya Ledak } \\
\text { Otot Tungkai } \pm \text { SB }\end{array}$} & \multirow[b]{2}{*}{$\mathrm{t}$} & \multirow[b]{2}{*}{$\mathrm{p}$} \\
\hline & $\begin{array}{l}\text { Sebelum } \\
\text { Pelatihan } \\
(\mathrm{cm})\end{array}$ & $\begin{array}{l}\text { Sesudah } \\
\text { Pelatihan } \\
(\mathrm{cm})\end{array}$ & & \\
\hline K. I & $\begin{array}{l}39,73 \pm \\
3,74\end{array}$ & $\begin{array}{l}55,64 \pm \\
4,03\end{array}$ & $-8,09$ & 0,000 \\
\hline K. II & $\begin{array}{l}39,73 \pm \\
3,58\end{array}$ & $\begin{array}{l}51,36 \pm \\
3,85\end{array}$ & $-7,56$ & 0,000 \\
\hline
\end{tabular}

Rerata hasil daya ledak otot tungkai antara sebelum dan sesudah pelatihan pada kelompok I dan kelompok II menunjukkan nilai $\mathrm{p}$ lebih kecil dari 0,05 , sehingga terdapat peningkatan hasil daya ledak otot tungkai pada masing-masing kelompok secara bermakna.

Dengan demikian pelatihan plyometric depth jump dan pelatihan standing jump berpengaruh signifikan terhadap peningkatan hasil daya ledak otot tungkai.

\section{PEMBAHASAN}

Hasil daya ledak otot tungkai pada tes awal dan tes akhir kelompok I (pelatihan plyometric depth jump) dengan menggunakan uji t-paired test didapat bahwa hasil rerata daya ledak otot tungkai sebelum dan sesudah pelatihan memiliki nilai $p=0,00$. Nilai tersebut menyatakan bahwa rerata hasil daya ledak otot tungkai antara sebelum dan sesudah pelatihan pada kelompok plyometric depth jump memiliki nilai p yang lebih kecil dari 0,05. Disimpulkan bahwa tipe pelatihan yang sudah dilaksanakan secara statistik berpengaruh signifikan terhadap peningkatan hasil daya ledak otot tungkai.

Peningkatan kemampuan daya ledak otot tungkai pada kelompok plyometric depth jump disebabkan karena adaptasi kontraksi otot terhadap pemberian beban yang diberikan selama pelatihan berlangsung. Pada pelatihan plyometric depth jump melibatkan anggota gerak tubuh bagian bawah ${ }^{7}$. Dari bentuk latihan plyometric depth jump mempunyai karakteristik kontraksi otot yang selalu 
berkontraksi baik saat memanjang maupun saat memendek dalam waktu yang cepat ${ }^{8}$.

Dari analisis data hasil daya ledak otot tungkai pada tes awal dan tes akhir kelompok II (pelatihan standing jump) menggunakan uji t-paired test didapatkan bahwa rerata hasil daya ledak otot tungkai sebelum dan sesudah pelatihan memiliki nilai $\mathrm{p}$ yang lebih kecil dari 0,05 . Sehingga dinyatakan bahwa tipe pelatihan yang sudah diterapkan secara statistik berpengaruh signifikan terhadap peningkatan hasil daya ledak otot tungkai.

Peningkatan daya ledak otot tungkai terjadi pada kelompok standing jump diakibatkan karena diyakini terjadi pembesaran pada masing-masing serabut otot sehingga terjadi peningkatan jumlah filamen aktin dan miosin pada serabut otot tersebut ${ }^{9}$. Semakin sering pelatihan dilakukan maka terjadi peningkatan fibril otot sehingga menyebabkan adanya peningkatan kekuatan otot ${ }^{10}$.

Perbedaan hasil daya ledak otot tungkai sebelum pelatihan dan sesudah pelatihan antara kelompok I (pelatihan plyometric depth jump) dan kelompok II (pelatihan standing jump) yang dianalisis menggunakan uji t-independen test. Hasil daya ledak otot tungkai pada kedua kelompok setelah pelatihan memiliki peningkatan yang berbeda. Peningkatan hasil kelompok I lebih besar dibandingkan dengan kelompok II, kelompok I memiliki hasil rerata sebelum pelatihan $39,73 \pm 3,74$ $\mathrm{cm}$ meningkat setelah diberikan pelatihan menjadi 55,64 $\pm 4,03 \mathrm{~cm}$. Sedangkan pada kelompok II $39,73 \pm 3,58 \mathrm{~cm}$ meningkat sebesar 51,36 $\pm 3,85 \mathrm{~cm}$ setelah pelatihan.

Otot-otot yang terlibat dalam gerakan meloncat pada kedua kelompok penelitian ini adalah anggota gerak tubuh bagian bawah ${ }^{7}$. Adanya peningkatan ukuran mitokondria sel otot menyebabkan secara fisiologis merangsang perbaikan pengambilan oksigen pada otot ${ }^{11}$. Perubahan yang terjadi pada serabut otot putih akan meningkatkan kecepatan otot sehingga dengan peningkatan kekuatan dan kecepatan akan menghasilkan daya ledak yang lebih baik ${ }^{12}$.

Kelompok yang diberikan pelatihan plyometric depth jump dimulai dengan sikap berdiri pada ujung box, Jatuhkan tubuh atau turun dari box ke tanah dengan kedua kaki dan lutut ditekuk. Setelah mendarat segera mulai meloncat keatas depan menuju box berikutnya. Sedangkan pada pelatihan standing jump diawali dengan berdiri dengan dua kaki selebar bahu dibelakang rintangan, kemudian melakukan loncatan ke depan atas dengan posisi badan tetap pada garis lurus melewati rintangan dengan kaki ditekuk dan mendarat dengan dua kaki.

Perbedaan jenis gerakan yang diberikan memberi pengaruh yang berbeda terhadap pembentukan kemampuan pada subjek pada saat pelatihan. Pengaruh pelatihan plyometric dept jump mendapatkan hasil yang lebih besar karena pada bentuk pelatihan ini mendapat dua kali pembebanan yaitu beban gravitasi dan berat badan dari subjek itu sendiri ${ }^{13}$. Sedangkan pada bentuk pelatihan standing jump hanya mendapatkan beban dari tubuh subjek itu sendiri untuk melakukan loncatan melewati penghalang pada saat pelatihan. Sehingga dari kedua bentuk pelatihan tersebut mendapatkan hasil pengaruh pelatihan yang berbeda pada masing-masing kelompok. Dimana repetisi dan set dalam pelatihan sudah dibuat sama.

\section{SIMPULAN}

Hasil penelitian yang telah dilakukan, disimpulkan bahwa :

Pelatihan Plyometric Depth Jump meningkatkan daya ledak otot tungkai lebih besar daripada pelatihan Standing Jump pada siswa peserta ekstra kurikuler bola voli SMK Triatma Jaya Badung.

\section{SARAN}

Berdasarkan hasil simpulan penelitian ini, disarankan untuk upaya peningkatan daya ledak otot tungkai sebagai berikut: 
1. Bagi pelaku olahraga (atlet, guru olahraga, dan pelatih olahraga) dapat menggunakan tipe pelatihan plyometric depth jump sebagai upaya peningkatan daya ledak otot tungkai sesuai tujuan yang ingin dicapai.

2. Bagi peneliti lain, hasil penelitian ini dapat dipergunakan sebagai acuan dalam melaksanakan penelitian mengenai peningkatan daya ledak otot tungkai.

\section{DAFTAR PUSTAKA}

1. Sukadiyanto \& Muluk D. 2011. Pengantar Teori dan Metodologi Melatih Fisik. Bandung: Lubuk Agung.

2. Nala, N. 2002. Prinsip Pelatihan Fisik Olahraga. Denpasar: Universitas Udayana.

3. Harsono. 2015. Periodisasi Program Pelatihan. Bandung: Rosda.

4. Sugiyono. 2008. Sejarah, Teknik dan Metode Permainan Bolavoli. Malang: IKIP Malang.

5. Lubis, J. 2005. Mengenal Latihan Pliometrik. Diakses tanggal 2/3/2017 dari

https://www.scribd.com/doc/81841013/

4-Mengenal-Latihan-Pliometrik.

6. Pocock, S. J. 2008. Clinical Trial;A Practical Approach. New York: A Willey Medical Publication.

7. Furqon \& Doewes. 2002. Pliometrik Untuk Meningkatkan Power, Surakarta: Program Study Ilmu Keolahragaan Program Pascasarjana Universitas Sebelas Maret.

8. Hasanah. 2013. "Pengaruh Latihan Pliometrik Depth Jump Dan Jump To Box Terhadap Power Otot Tungkai Pada Atlet Bola Voli Klub Tugumuda Kota Semarang” (Skripsi). Semarang: Universitas Negeri Semarang.

9. Guyton, A.C., Hall, J.E. 2007. Fisiologi Kedokteran (terjemahan). Jakarta: Penerbit Buku Kedokteran EGC.

10. Sudiartha, I. W. 2011. "Pelatihan Lompat Rintang Lima Repetisi Tiga Set Meningkatkan Hasil Lompatan Lompat Jauh Siswa SMA Negeri 1 Amlapura". (Tesis). Denpasar: Universitas Udayana.
11. Bompa, T. O. 2005. Periodization training for sport, 5th Edition. Kendall/Hunt: Publishing Company.

12. Widiantari, Sutjana I.D.P dan Adiatmika I.P.G. 2015. "Perbandingan Loncat Rintangan $50 \mathrm{~cm}$ dengan Variasi Lari Cepat 5 Meter Antara 10 Repetisi 3 Set dan 5 Repetisi 6 Set Terhadap Peningkatan Tinggi Loncatan Vertical Pada Mahasiswa Semester II Putra di FPOK IKIP PGRI BALI". Denpasar. ISSN:2302-688X. Sport and Fitness Journal Volume 3, No.2 : 67-7

13. Sulaksono, G. 2015. "Pengaruh Latihan Pliometrik Depth Jump Terhadap Peningkatan Daya Ledak Otot Tungkai Dalam Smash Pada Permainan Bola Voli Siswa SMK Plus Darus Salam Kota Kediri Tahun Ajaran 2014/2015”. (Skripsi). Kediri: Universitas Nusantara PGRI Kediri 
